\title{
Body Mass Index and Triglyceride Levels of the Students of Faculty of Medicine University of North Sumatra 2016
}

\author{
Nenni Dwi Aprianti Lubis ${ }^{1}$, Mutiara Indah Sari ${ }^{2}$ \\ ${ }^{I}$ Nutrition Department, University of North Sumatra, Indonesia \\ nennidapriantilubis@yahoo.co.id \\ ${ }^{2}$ Biochemistry Department, University of North Sumatra, Indonesia \\ muti_dr@yahoo.com
}

\begin{abstract}
Body mass index (BMI) is an approximate measure of your total body fat. Being underweight or overweight can cause health problems, especially if you are also inactive. These problems include heart disease and cardiovascular problems, diabetes, digestive problems, breathing problems and other problems. This research aims to know the relationship of BMI and triglyceride level in the blood on the students of Faculty of Medicine, University of North Sumatra (FK USU) in 2016. This research type is analytic with cross-sectional design, using a consecutive sampling technique of 139 people. Data collection techniques were carried out by using various variables, first, the measurement of weight and height to get the BMI data and blood samples were taken for levels of triglycerides in the blood data. Data was analysed using Pearson correlation test. The result showed that BMI correlates with levels of triglycerides by 0.33 . The value of $r$ of $B M I$ relationship with triglyceride level is 0.0001. The significance value of $<0.05$ is seen thus there is a correlation between the two real variables. As much as $\mathbf{1 0 . 8 9 \%}$ difference in triglyceride levels can be explained by BMI.
\end{abstract}

Keywords - BMI, triglyceride levels

\section{INTRODUCTION}

The change in lifestyle because of wealth increment has led to the increasing number of people with obesity, as in [1]. It comprises of high fat contained diet and low physical activities. Reference [2] per BPS in 2012, it was found that only $24.99 \%$ of the population aged above 10-year old partake in physical activities. University students are busy with numerous personal and social activities which make them unable to consume healthy and nutritious meals. Fast food meals are the main option for majority of university students, even though those meals do not contain nutrients composition needed by human body.

Food containing high level of fat will not satisfy the hunger but provide savoury flavour. To satisfy the hunger, they will consume food in a higher amount. The huge amount of food intake high in fat will produce high energy. That habit causes the imbalance of fat storage in adipose tissue, which will cause fat hoarding in the body.

The evaluation of nutritional status by anthropometry method, using Body Mass Index (BMI), is an assessment indicator in analysing body's proportion. Obesity is an over-weight body condition due to fat hoarding, and the percentage for both male and female are more than $20 \%$ and $25 \%$ of total body mass respectively, as in [3].

Nutritional status status may impact the lipid profile. Triad lipid consists of total cholesterol value, low density lipoprotein (LDL), high density lipoprotein (HDL) and triglycerides. Genetic factors, age and gender are affecting factors of lipid profile, as well as dietary habit, alcohol consumption, smoking and physical activities.

\section{METHOD}

\section{A. Design, Location and Time of Research}

Research design is cross sectional, conducted from February until September 2016. This research is performed in Laboratorium Terpadu, Faculty of Medicine, University of North Sumatra (FK USU).

\section{B. Population and Sampling Technique}

Population in this research are students at FK USU. 139 samples were selected by using consecutive sampling. All samples signed the inform consent to show their agreement to participate in this research.

\section{Type and Data Collection}

Data collected in this research is primary data. Data of samples characteristic were gathered 
through interview by distributing questionnaires. The body weight and height were executed directly. In addition to that, data of triglycerides were obtained through laboratory analysis in laboratory's USU Hospital.

\section{Data Processing and Analysis}

Descriptive analysis was used to illustrate the characteristic of samples, BMI and triglycerides consumption. BMI is acquired by comparing between body weight in Kilogram $(\mathrm{Kg})$ divided by height in metre square. The triglycerides were obtained from the laboratory based on the blood sample of respondents. Pearson correlation test was also applied in order to know the relationship between research variables (SPSS 20).

\section{RESULTS AND DISCUSSION}

The characteristic of samples can be seen in Table 1. The highest proportion of samples are female at $60.43 \%$.

TABLE I

THE CHARACTERISTIC OF SAMPLES

\begin{tabular}{|l|c|c|}
\hline \multicolumn{1}{|c|}{ Gender } & $\mathrm{n}$ & $\%$ \\
\hline Male & 55 & 39.57 \\
\hline Female & 84 & 60.43 \\
\hline Total & 100 & 100.00 \\
\hline
\end{tabular}

\section{A. IBM and Nutrition Status of Samples IMT}

Table 2 clearly demonstrates that the BMI's mean value is $26.25 \pm 5.81 \mathrm{Kg} / \mathrm{m}^{2}$ (Table 2). Refer to the nutritional status based on Asian adult criteria, there are 90 samples classified as overweight and obese with $\mathrm{BMI} \geq 23,40$ samples are normal and the rest which are 9 samples, are classified in underweight group with BMI less than 18.5 (Table 3).

TABLE II

BMI AND LEVEL OF TRIGLYCERIDES

\begin{tabular}{|l|c|c|}
\hline \multicolumn{1}{|c|}{ Variables } & BMI & Triglyceride Levels \\
\hline Mean & 26.25 & 81.7 \\
\hline Standard deviation & 5.81 & 56.4 \\
\hline Maximum value & 44.27 & 454.0 \\
\hline Minimum value & 16.41 & 32.0 \\
\hline
\end{tabular}

TABLE III

THE DISTRIBUTION OF NUTRITIONAL STATUS BASED ON BMI OF ASIAN ADULT CRITERIA

\begin{tabular}{|l|c|c|}
\hline Nutritional Status & $\mathrm{n}$ & $\%$ \\
\hline Underweight & 9 & 6.5 \\
\hline Normoweight & 40 & 28.8 \\
\hline Overweight & 15 & 10.8 \\
\hline Obesity & 75 & 53.9 \\
\hline \multicolumn{1}{|c|}{ Total } & & 100.0 \\
\hline
\end{tabular}

\section{B. Lipid Profile and Blood Sample}

The mean of lipid profile is presented in the form of triglycerides level in the body. The average of triglycerides level of samples is $81.7 \pm 56.4 \mathrm{mg} / \mathrm{dl}$ (Table 2).

Table 4 shows large number of samples have normal range of triglyceride levels (133 samples). However, there are only 5 samples categorized in borderline high and 1 sample is at high level. The very high level of triglycerides is not seen in any samples.

TABLE IV

THE DISTRIBUTION OF TRYGLICERIDE LEVELS

\begin{tabular}{|l|c|c|}
\hline Interpretation and level $(\mathrm{mg} / \mathrm{dL})$ & $\mathrm{n}$ & $\%$ \\
\hline Normal range $(<150)$ & 133 & 96.7 \\
\hline Borderline high $(150-199)$ & 1 & 0.7 \\
\hline High $(200-499)$ & 5 & 3.6 \\
\hline Very high : highest risk $(>500)$ & 0 & 0.0 \\
\hline Total & 100 & 100.0 \\
\hline \multicolumn{2}{|c|}{}
\end{tabular}

\section{The Relationship of BMI and Level of Triglycerides}

Results has shown that BMI has correlation with the level of triglycerides in the blood, of the students of Faculty of Medicine USU, with $r=0.33$; $\mathrm{p}=0.001$. Pearson Correlation result demonstrated that $10.89 \%$ differences of triglycerides can be explained by BMI. This result is supported by the research done by [4] on students at University of Sanata Yogyakarta - Campus III, who explained that the measurement of BMI and waist size have positive correlation, which means it has medium correlation strength with the level of triglycerides in blood. The accumulated triglycerides in adipose tissue may enlarge the fatty cell and cause proliferation that lead to obesity. That result is also aligned with previous studies in several countries such as Seidell et al. (2001) in Canada, Dalton et al and Welborn et al. (2003) in Australia, Knowles et 
al. (2013) in Peru; and Wai et al. (2013) in Ethiopia, as in [4].

Student of FK USU in their daily activities more spend time on campuss, so that, their daily food selection more on fast food. Reference [5] stated that there is a relationship between the food quality score with the level of triglycerides, the better dietary habit, the lower the higher-triglycerides occurrence will be. High fat and inadequate fiber consumption are considered as the cause of triglycerides level escalation. This is in line with research by [7], who affirmed that vegetables and fruits consumption is associated with the level of triglycerides.

Lack of physical activity has also led to increase weight gain. Physical activities are an important determinant of energy expenditure, balance energy and weight control, as in [8].

\section{CONCLUSION}

The average BMI's score of samples can be categorized in obesity (BMI $\geq 25$ ). Overall, samples have normal level of triglycerides. Based on Pearson correlation test, there is a relationship between BMI and the level of triglycerides.

\section{ACKNOWLEDGEMENT}

Lembaga Penelitian of University of North Sumatra is duly appreciated for the funding through Hibah Bersaing 2016.

\section{REFERENCES}

[1] Almatsier, S, Principles of Nutrition. Jakarta : Gramedia Pustaka Utama, 2010.

[2] (2016) BPS website. [Online]. Available : https://www.bps.go.id/linkTabelStatis/view/id/1524

[3] Hill, J.O., Obesity : Etiology in Modern Nutrition in Health and Disease. USA : Lippincot Williams \& Wilkins, 2005.

[4] Supariasa, I.D.N, B. Bakri, and I. Fajar. Nutritional Status. Jakarta, EGC, 2001.

[5] Pangesti, B.W, D.I. Sari, and Fenty. Correlation of Antropometry Measurement and the Level of Triglyceride on Adolescense. Pharmacy, vol.11, pp.157-165, Des, 2014.

[6] Liliany, E.I, N. Jafar,and U. Najamuddin. "Relationship of Physical Activity and Eating Patterns to Components of the Metabolic Syndrome on Diabates Mellitus Type 2 Patient in The Work Area Health Center Makasar.,"SKM thesis, Universitas of Hasanuddin, Makasar, Agustus. 2013.

[7] Nashriati, W.O.A, N. Jafar, and R. Indriasari. "Relationship between Diatary Pattern by Diet Quality Score with Lipid Profile among Outpatient Type 2 DM in the Working Area of Makasar City Health Center.,"SKM thesis, Universitas of Hasanuddin, Makasar, Agustus. 2014.

[8] (2016) WHO website. [Online]. Available : http://www.who.int/dietphysicalactivity/pa/en/ 